\title{
Perancangan Interior Laboratorium Material Dan Sistem Pencahayaan Di PS/Jurusan Desain Interior ISI Denpasar
}

\author{
Toddy Hendrawan Yupardhi, Ni Luh Kadek Resi Kerdiati
}

Program Studi Desain Interior Fakultas Seni Rupa dan Desain

Institut Seni Indonesia Denpasar

odixawan@gmail.com

Penelitian dan Penciptaan Karya terkait dengan upaya untuk merancang sebuah laboratrium material interior dan sistem pencahayaan interior. Metode yang digunakan dalam penelitian ini adalah metode kualitatif dengan pendekatan studi kasus yang disampaikan secara deskriptif. Sedangkan metode penciptaan dalam merancang interior Laboratorium Material dan Sistem Pencahayaan ini menggunakan metode Research Based Design (RBD). Adapun 4 fase dari Metodologi RBD sebagai berikut (1) Penyelidikan Kontekstual (Contextual Inquiry) (2) Desain partisipatoris (Participatory Design) (3) Desain Awal (Preliminary Design) (4) Desain Konseptual (Prototype as Hypothesis). Lokasi kasus yang akan digunakan dalam proses perancangan adalah Ruang Studio Interior di Gedung Ida Bagus Nyatna ISI Denpasar. Output dari proses penelitian dan penciptaan karya ini adalah berupa dokumen gambar konsepsual dan gambar kerja pengembangan desain. Hasil Penelitian dan Penciptaan Seni berupa rancangan Interior Laboratorium Material dan Sistem Pencahayaan ini diharapkan dapat menjadi tonggak awal dalam pengadaan fasilitas tersebut guna tercapainya tujuan peningkatan kualitas serta mutu pendidikan di PS/Jurusan Desain Interior ISI Denpasar.

\section{Kata Kunci: Laboratorium, interior, pencahayaan, bahan}

This research based design aim to design a material and lighting system laboratory for interior design students. The method for the research is a qualitative method with a descriptive case study approach. The method of conceptual design creation for the Material Laboratory and Lighting System using the Research Based Design (RBD) method. The 4 phases of the RBD Methodology are as follows (1) Contextual Inquiry (2) Participatory Design (3) Preliminary Design (4) Conceptual Design (Prototype as Hypothesis). The location use for the design process is the Interior Studio Room at Ida Bagus Nyatna Building, ISI Denpasar. The output of the research and designing creation process is a conceptual drawing document and a design development drawing documents. The results of the Penciptaan dan Penelitian Seni (P2S) research in the designing of Material Laboratory Interior Design and Lighting Systems are expected to be an initial milestone in the procurement of these facilities in order to achieve the goal of quality improvement of education at the Department of Interior Design ISI Denpasar.

Key Words: Laboratory, interior, lighting, material 


\section{PENDAHULUAN}

Desainer interior merupakan salah satu profesi yang makin diminati belakangan ini. Semakin terbukanya informasi dan cepatnya arus teknologi, memberi ruang gerak bagi desain interior untuk muncul, dikenal dan menjadi salah satu kebutuhan pada tiap lapisan masyarakat. Secara akademis, keilmuan desain interior menekankan pada proses perencanaan yang melibatkan konsep dan menghasilkan solusi berupa rancangan atau desain. Keilmuan desain interior merupakan keilmuan terapan yang tidak hanya mencakup pada pengajaran berbagai teori tentang desain, namun juga bagaimana aplikasi dan berbagai macam elemen penunjangnya terlebih apabila rancangan tersebut diwujudkan secara nyata. Material atau bahan pembentuk interior dan sistem pencahayaan merupakan dua elemen dasar yang terlibat langsung sebagai pemecahan masalah dan memberikan nilai pembeda pada setiap rancangan interior. Kebutuhan informasi mengenai material interior dan sistem pencahayaan kemudian menjadi bagian penting dalam proses akademik pada sebuah institusi penyelenggara keilmuan Desain Interior.

Program Studi (PS)/Jurusan Desain Interior ISI Denpasar merupakan salah satu institusi negeri penyelenggara proses belajar mengajar keilmuan desain interior. Dalam silabus kurikulumnya, sebagaimana layaknya perguruan tinggi penyelenggara keilmuan desain interior lainnya, PS/ Jurusan Desain Interior ISI Denpasar menyematkan mata kuliah terkait pengenalan material yang digunakan dalam perancangan interior yakni Pengetahuan Bahan Interior dan juga pengenalan mengenai sistem pencahayaan didalam mata kuliah Utilitas Interior. Kedua mata kuliah ini merupakan mata kuliah yang banyak memberikan informasi dan mengajarkan mengenai apa dan bagaimana peranan material serta keterlibatan sistem pencahayaan dalam sebuah rancangan interior secara teoritis dan aplikatif. Selama ini mata kuliah Pengetahuan Bahan Interior dan Utilitas Interior lebih banyak dilakukan dalam kelas untuk materi teoritisnya, dan memberikan tugas mandiri kepada mahasiswa untuk terjun langsung ke lapangan, melihat dan mendokumentasikan baik itu material interior maupun sistem pencahayaan interior yang beredar dan digunakan di masyarakat. Ini disebabkan karena untuk proses aplikatifnya, PS/Jurusan Desain Interior ISI Denpasar belum memiliki fasilitas khusus material interior dan sistem pencahayaan interior yang dapat menunjang proses belajar mengajar dengan lebih baik. Hal ini tentunya menjadi sebuah tantangan bagi kelancaran proses transfer keilmuan guna mencapai mutu yang lebih baik.

Keberadaan ruang laboratorium sebagai fasilitas pendukung kegiatan riset pada perguruan tinggi merupakan salah satu syarat fasilitas penunjang yang tercantum dalam borang akreditasi BANPT. Penilaian mutu dari suatu proses kegiatan perkuliahan dapat dipengaruhi dari ketersediaan fasilitas-fasilitas penunjang tersebut. PS/Jurusan Desain Interior ISI Denpasar dengan status akreditasi A tentunya ingin mempertahankan status akreditasinya, untuk dapat bersaing dengan lebih baik dan meningkatkan kualitas hasil didikannya.

Berdasarkan uraian diatas dapat dirumuskan sebuah pernyataan tentang permasalahan yang ingin dipecahkan yakni : Bagaimana proses penelitian skenario aktivitas dan hasil rancangan konsepsual yang dicapai terkait kebutuhan PS/Jurusan Desain Interior ISI Denpasar akan Laboratorium Material dan Sistem Pencahayaan untuk menunjang kegiatan belajar mengajar, penelitian dan eksperimen.

\section{TINJAUAN PUSTAKA}

Laboratorium diambil dari bahasa Latin "labora" yang berarti bekerja. Deskripsi dari laboratorium terkait dengan posisinya di dunia pendidikan tertera dalam Permenpan No. 03 tahun 2010 yang menyebutkan bahwa Laboratorium pendidikan adalah unit penunjang akademik pada lembaga pendidikan, berupa ruangan tertutup atau terbuka, bersifat permanen atau bergerak, dikelola secara sistematis untuk kegiatan pengujian, kalibrasi dan atau produksi dalam skala terbatas, dengan menggunakan peralatan dan bahan berdasarkan metode keilmuan tertentu, dalam rangka pelaksanaan pendidikan, penelitian dan pengabdian kepada masyarakat. Definisi lain dari Decaprio (2013: 16) menyebutkan bahwa laboratorium adalah tempat sekelompok orang yang melakukan berbagai macam kegiatan penelitian (riset) pengamatan, pelatihan dan pengujian ilmiah sebagai pendekatan antara teori dan praktik dari berbagai macam disiplin ilmu. Dengan demikian dapat disimpulkan bahwa laboratorium dalam konteks akademik adalah sebuah tempat yang dikelola secara sistematis dengan fasilitas, peralatan dan bahan berdasarkan metode keilmuan tertentu dan dipergunakan sebagai tempat pelaksanaan 
pendidikan, kegiatan pengamatan, riset, eksperimen maupun pelatihan dan pengujian ilmiah dalam rangka upaya pendekatan antara teori dan praktik.

Dalam dunia desain interior, peranan elemen material sangat sentral dalam membentuk fisik ruang dan fasilitas di dalamnya, dengan berbagai macam variasi tampilan, fungsi, konstruksi, finishing, hingga lebih jauh kepada makna atau pesan tertentu yang ingin disampaikan. Material sendiri berkembang seiring dengan perjalanan waktu, bukan hanya melalui kehadiran material baru, namun juga penggunaan material lama dengan cara baru yang juga kerap ditampilkan.

Melihat beragamnya variasi material yang ada, pemahaman mengenai material interior terutama dari karakteristik dan fungsinya akan memudahkan perancang interior dalam memilih dan memilah material apa saja yang dapat mendukung kreasi mereka dalam merancang sebuah ruang dengan fasilitasnya yang sesuai untuk kebutuhan pengguna, menyampaikan pesan tertentu, bahkan menciptakan trend baru melalui karakter material yang tepat.

Setiawan (2005:70) dalam penelitiannya menyebutkan bahwa banyak kendala umumnya muncul terkait pada ketidakmampuan mahasiswa untuk mengetahui dan mengenali karakteristik bahan yang berpotensi untuk digunakan sebagai material pembentuk elemen interior. Setidaknya ada empat permasalahan pokok yang kerap dijumpai terkait pemahaman mahasiswa tentang material yaitu:

1. Tidak mengetahui wujud material yang menjadi item perancangan

2. Tidak mengetahui dimensi standar material atau produk bahan interior yang ada

3. Tidak mengetahui model-model baru yang berkembang dari material atau produk bahan interior di pasaran

4. Tidak mengetahui bagaimana konstruksi, sistem pemasangan dan cara kerja material atau produk bahan interior.

Kelemahan ini kemudian membuat munculnya berbagai kendala seperti perubahan desain yang berulang-ulang, baik dari segi bentuk, kenyamanannya bahkan konsep perancangannya. Tidak jarang juga menjadi penghambat dalam berkreasi untuk memunculkan ide-ide baru, dan yang fatal adalah kesalahan dalam penggunaan serta menyusun atau mengkontruksi material yang dapat menyebabkan kecelakaan ataupun hal yang tidak diinginkan lainnya.

Sebenarnya informasi mengenai material sendiri dengan pesatnya kemajuan teknologi bisa didapatkan melelui media internet. Namun ada informasi yang tidak dapat secara langsung direkam oleh mahasiswa adalah aspek tekstur yang terkait dengan sentuhan (tactile) dan aroma (olfaktorial). Ini tentu dapat mengurangi informasi yang semestinya menyeluruh didapatkan oleh mahasiswa mengenai material tersebut. Sedangkan dalam perancangan tuntutan akurasi yang tinggi dari setiap elemen interior dibutuhkan karena dapat mempengaruhi kualitas hasil akhir perancangan.

Tidak jauh berbeda dengan material, sistem pencahayaan juga memberikan pengaruh besar pada rancangan interior. Elemen pencahayaan bersama warna merupakan salah satu alat dalam desain interior yang paling kuat. Sistem pencahayaan tidak hanya membantu dalam pengerjaan sebuah kegiatan, namun juga mempengaruhi sikap dan perilaku manusia. Bahkan sistem pencahayaan juga menciptakan suasana dan karakteristik tertentu dalam sebuah ruang (Kilmer \& Kilmer, 1992: 123). Jenis pencahayaan dalam desain interior umumnya dibagi menjadi dua kelompok besar yakni sistem pencahayaan alami dan sistem pencahayaan buatan (artificial). Sistem pencahayaan alami memanfaatkan sinar matahari ataupun sumber cahaya lain yang terdapat di alam, sedangkan sistem pencahayaan buatan secara umum diasosiasikan sebagai sistem pencahayaan elektrik. Pengaturan kedua sistem pencahayaan ini yang kemudian menjadi tantangan bagi mahasiswa untuk dapat menampilkan potensi terbaik dari rancangan interior yang mereka buat.

Pengaturan kuat intensitas cahaya, warna cahaya, jenis sumber cahaya dan posisi penempatannya memberikan pengaruh terhadap kondisi ruang interior yang ingin dicapai. Mahasiswa dituntut untuk minimal dapat memahami dan memberikan solusi praktis dengan berkreasi menggunakan berbagai jenis sistem pencahayaan yang menurut Dodsworth (2009: 140) antara lain adalah:

1. General dan ambient lighting: pencahayaan secara umum untuk menerangi ruang dan melakukan kegiatan standar

2. Accent/ feature lighting: Pencahayaan untuk menambahkan detail atau kesan pada sebuah skema interior. 
3. Tasklighting: menekankan pencahayaan spesifik untuk melakukan detail pekerjaan tertentu.

4. Decorative lighting: pencahayaan untuk tujuan dekorasi, tidak mengarah pada penerangan spesifik.

5. Kinetic lighting: sumber pencahayaan yang berasal dari alam seperti api (lilin atau perapian), yang dapat menambahkan efek gerak dalam interior.

Untuk dapat memahami bagaimana aplikasi sistem pencahayaan dalam sebuah ruang, mahasiswa tidak cukup hanya membaca teori dan menghitung kebutuhan jumlah sumber penerangan yang akan digunakan. Bagaimana efek cahaya dan bayangan yang ditimbulkan juga perlu diketahui dan dialami agar nantinya mahasiswa menjadi lebih peka dalam memilih sistem pencahayaan yang sesuai dengan peruntukan rancangan ruangnya.

\section{METODE PENELITIAN DAN PENCIPTAAN}

Metode penelitian dan penciptaan menggunakan metode Research Based Design (RBD). Metode ini dikemukakan oleh Teemu Leinonen, terinspirasi oleh teori-teori desain (Leinonen \& Durall, 2014). Pembangunan prototype desain, penekanan solusi kreatif, eksplorasi ide-ide dari berbagai konsep desain, evaluasi berkelanjutan dan pengembangan dari suatu solusi desain menjadi fokus dari metodologi RBD ini. Penelitian dengan metode RBD akan lebih dekat pada penelitian artistic dibandingkan dengan penelitian eksak, karena selain bertujuan untuk menghasilkan karya baru, juga harus dapat menghasilkan pengetahuan tentang proses penciptaan dari karya tersebut.

Adapun tahapan penelitian dilaksanakan sebagai berikut:

1. Melakukan penelitian mengenai aktivitas apa saja yang dilakukan, jumlah pelaku aktivitas (civitas), waktu pelaksanaan aktivitas dan jenis fasilitas pendukung yang dibutuhkan pada proses belajar mengajar. Bagian penelitian ini dilakukan secara simulatif dengan melibatkan beberapa mahasiswa dan dosen sebagai partisipan untuk melihat pola aktivitas, runtutan kegiatan dan rekaan jenis fasilitas yang dibutuhkan.

2. Membuat tabulasi hasil penelitian sebagai data awal proses penciptaan desain. Data ini kemudian dianalisa untuk mengungkapkan permasalahanpermasalahan yang muncul dari ketidaksesuaian antara idealita dari civitas dengan kondisi riil atau fakta di lapangan.

3. Berdasarkan pada rumusan permasalahan yang muncul, kemudian dilakukan analisa untuk menghasilkan jawaban-jawaban tekstual (sintesa). Sementara itu pemilihan konsep perancangan juga dilakukan disesuaikan dengan kebutuhan jawaban desain sehingga dapat menjadi benang merah pengikat gagasangagasan desain nantinya. Gagasan-gagasan desain sendiri merupakan produk hasil sintesa yang dituangkan dalam bentuk visual (sketsa) dengan berdasar kepada kesesuaian konsep perancangan, kriteria desain, tujuan desain, rujukan literatur dan parameter sejenis. Gagasan desain kemudian kembali dianalisa sehingga dapat menghasilkan desain terpilih.

4. Langkah selanjutnya adalah proses awal penciptaan desain yakni dengan membuat program ruang (analisis kebutuhan ruang, kebutuhan fasilitas, besaran ruang, matriks hubungan antar ruang/area, zoning dan sirkulasi, hingga blockplan ruang). Program ruang ini akan mengarah pada langkah berikutnya yaitu penentuan denah tata letak ruang/ area lab material dan sistem pencahayaan ini. Tata letak ruang/ area merupakan hasil analisa dari penentuan zoning dan sirkulasi yang terjadi dalam ruang tersebut. Kemudian dilanjutkan dengan penentuan denah tata letak fasilitas, gambar potongan dan gambar-gambar perspektif beberapa view interior ruang laboratorium. Pada tahap ini desain konsepsual sudah selesai.

5. Guna melengkapi hasil rancangan yang mengarah kepada peluang untuk pelaksanaan atau realisasi, maka desain konsepsual kemudian dipresentasikan kepada jajaran struktural PS/ Jurusan Desain Interior ISI Denpasar dan dosendosen pengampu mata kuliah terkait untuk mendapatkan feedback bagi pengembangan desain konsepsual. Berbagai input tersebut kemudian dijadikan dasar atau landasan untuk membuat dokumen desain pengembangan dan gambar detail konstruksi.

\section{HASIL DAN PEMBAHASAN}

Secara umum konsep yang digunakan dalam perancangan termasuk kedalam konsep pragmatis yakni konsep perancangan yang mengutamakan pemecahan masalah dengan tanggapan langsung. Bentuk konsep ini mengutamakan hasil akhir 


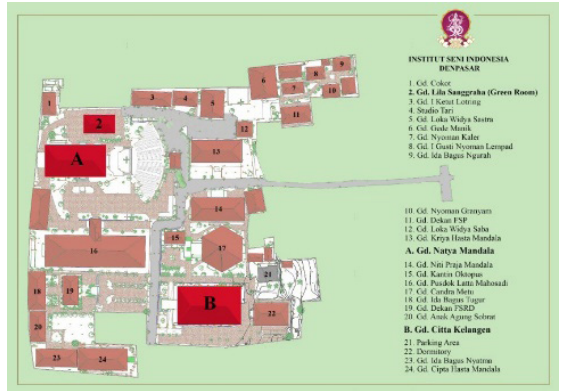

Gambar 1. Denah site lokasi kasus Sumber: www.isi-dps.ac.id

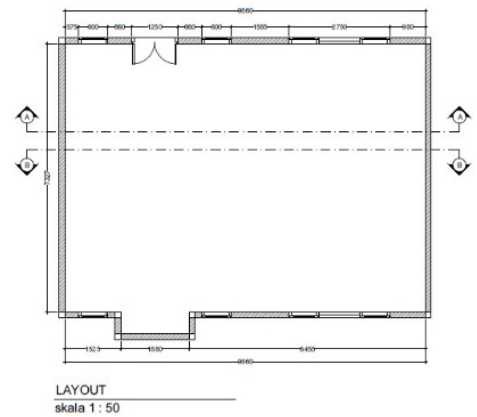

Gambar 2. Denah Ruang eksisting

Sumber: Dokumentasi Penulis 2020

sesuai fungsi, kebutuhan dan susunan ruang, tanpa mengacu bentuk tertentu, murni aspek teknikal. Konsep khusus perancangan menggunakan konsep "Smart Integrated Lab" yakni konsep yang mengintegrasikan beberapa sistem dalam desain interior yang ditampilkan dalam sebuah ruangan laboratorium dan dikelola secara terpadu dengan teknologi yang aplikatif. Integrasi teknologi digital menjadi bagian dalam aplikasi operasional laboratorium ini, dan juga sekaligus menjadi sampel untuk penerapannya dalam sebuah fasilitas ruang.

Lokasi yang akan digunakan sebagai lokasi laboratorium adalah ruang kelas (Studio Desain Interior) yang berada di ruang lantai 2 Gedung Ida Bagus Nyatna, bagian selatan dari area kampus ISI Denpasar. Ruang kelas ini sementara tidak digunakan untuk kegiatan belajar mengajar, hanya digunakan sebagai tempat pemajangan karya terpilih dari mahasiswa pada setiap semesternya dan sesekali waktu digunakan untuk kegiatan rapat mahasiswa. Kondisi ini kemudian memungkinkan untuk dilakukan pengembangan terhadap fungsi ruang menjadi laboratorium material dan sistem pencahayaan sesuai kebutuhan PS/Jurusan Desain Interior.
Gambar 1 menunjukkan denah site posisi bangunan tempat ruangan yang akan digunakan sebagai objek kasus perancangan laboratorium. Tertera pada gambar dengan bangunan nomor 23, terletak pada lantai dua bangunan, ruangan menghadap arah utara, diapit oleh dua ruangan laboratorium komputer dari PS/Jurusan Desain Komunikasi Visual dan PS/ Jurusan Fotografi.

Ruang eksisting memiliki ukuran as $7,5 \times 10 \mathrm{~m}$. Penambahan besaran ruang sudah tidak dapat dilakukan karena ruang berada pada bangunan permanen, bagian kanan dan kirinya diapit oleh ruang lain, dan ruang ekstra yang dapat digunakan hanya pada selasar depan.

Berdasarkan hasil wawancara terkait idealita civitas calon pengguna laboratorium material dan sistem pencahayaan dapat diketahui bahwa kriteria khusus dalam perancangan yang harus dapat dipenuhi antara lain adalah:

1. Memiliki sample material yang cukup untuk pengenalan bahan interior

2. Memiliki sample teknik aplikasi sistem pencahayaan dalam interior yang memadai

3. Dapat digunakan langsung sebagai ruang diskusi/ presentasi saat jam mata kuliah yang menggunakan lab.

4. Memiliki teknik display sample yang baik dan terjangkau

5. Menggunakan teknologi digital dalam pengoperasionalannya

6. Material fasilitas mudah dibersihkan, tahan api dan air, movable

7. Dapat melakukan riset skala kecil-menengah di laboratorium

8. Jumlah pelaku aktivitas maksimal 20 orang dalam satu waktu bersamaan (protocol kesehatan COVID-19)

Kriteria ini kemudian akan menjadi koridor dan syarat mutlak dari penciptaan desain laboratorium, sehingga idealita pengguna laboratorium dapat dipenuhi secara optimal.

Penentuan skenario aktivitas kemudian diketahui melalui hasil penelitian simulasi penggunaan laboratorium dengan partisipan beberapa dosen dan mahasiswa Desain Interior ISI Denpasar pada tanggal 10 Juli 2020. Berikut adalah tabulasi hasil simulasinya. 
Tabel 1. Tabulasi hasil simulasi

\begin{tabular}{|c|c|c|c|c|}
\hline No & Civitas & Aktivitas & Fasilitas & Ruang/Area \\
\hline \multirow[t]{6}{*}{1} & \multirow[t]{6}{*}{ Laboran } & Datang, masuk, menyimpan barang & Loker & Selasar/teras \\
\hline & & registrasi & Booth Registrasi & Area registrasi \\
\hline & & Menyiapkan ruangan & $\begin{array}{l}\text { Meja kerja, kursi, } \\
\text { Computer set }\end{array}$ & Area Laboran \\
\hline & & $\begin{array}{l}\text { - Menjaga Lab } \\
\text { - menyiapkan kebutuhan praktikum } \\
\text { - Mengembalikan sampel ke rak nya } \\
\text { - Mengerjakan Laporan harian } \\
\text { - Menerima tamu } \\
\text { - aktivitas bersih diri }\end{array}$ & $\begin{array}{l}\text { Meja kerja, kursi, } \\
\text { Computer set }\end{array}$ & $\begin{array}{l}\text { Area Laboran, } \\
\text { Area Diskusi } \\
\text { Area Display } \\
\text { Toilet }\end{array}$ \\
\hline & & istirahat & - & - \\
\hline & & $\begin{array}{l}\text { - Menjaga Lab } \\
\text { - menyiapkan kebutuhan praktikum } \\
\text { - Mengembalikan sampel ke rak nya } \\
\text { - Mengerjakan Laporan harian } \\
\text { - Menerima tamu } \\
\text { - aktivitas bersih diri } \\
\text {-pulang }\end{array}$ & $\begin{array}{l}\text { Meja kerja, kursi, } \\
\text { Computer set } \\
\text { Booth registrasi }\end{array}$ & $\begin{array}{l}\text { Area Laboran, } \\
\text { Area Diskusi } \\
\text { Area Display } \\
\text { Toilet } \\
\text { Area registrasi }\end{array}$ \\
\hline \multirow[t]{4}{*}{2} & \multirow[t]{4}{*}{ Mahasiswa } & Datang, Masuk, Menyimpan barang bawaan & Loker & Selasar/teras \\
\hline & & registrasi & Booth Registrasi & Area registrasi \\
\hline & & $\begin{array}{l}\text {-Mencari sampel material } \\
\text {-Mengamati dan mencatat informasi material } \\
\text { dan pencahayaan } \\
\text { - Mendengarkan dan mengamati penjelasan } \\
\text { dosen } \\
\text { - Melakukan diskusi } \\
\text { - Melakukan eksperimen } \\
\text { - Praktik assembling } \\
\text { - Keluar }\end{array}$ & $\begin{array}{l}\text { Rak display, material } \\
\text { board } \\
\text { Meja kerja } \\
\text { Kursi, display lighting } \\
\text { Meja kerja } \\
\text { Kursi } \\
\text { Meja kerja } \\
\text { Kursi } \\
\text { Meja kerja } \\
\text { Kursi luxmeter, material } \\
\text { board }\end{array}$ & $\begin{array}{l}\text { Area display } \\
\text { Area Diskusi } \\
\text { Area Lighting display }\end{array}$ \\
\hline & & & Booth registrasi & Area registrasi \\
\hline \multirow[t]{4}{*}{3} & \multirow[t]{4}{*}{ Dosen } & Datang, Masuk, Menyimpan barang bawaan & Loker & Selasar/teras \\
\hline & & registrasi & Booth Registrasi & Area registrasi \\
\hline & & $\begin{array}{l}\text {-Mencari sampel material } \\
\text {-Mengamati dan mencatat informasi material } \\
\text { dan pencahayaan } \\
\text { - Memberikan penjelasan materi kuliah } \\
\text { - Melakukan diskusi } \\
\text { - Melakukan eksperimen pencahayaan/ material } \\
\text { - Praktik assembling } \\
\text { - Keluar }\end{array}$ & $\begin{array}{l}\text { Rak display, material } \\
\text { board } \\
\text { Meja kerja } \\
\text { Kursi, display lighting } \\
\text { Meja kerja } \\
\text { Kursi } \\
\text { Meja dosen } \\
\text { Kursi, Proyektor dan } \\
\text { screen } \\
\text { Meja kerja } \\
\text { Kursi, luxmeter, material } \\
\text { board }\end{array}$ & $\begin{array}{l}\text { Area display } \\
\text { Area Diskusi } \\
\text { Area Lighting display }\end{array}$ \\
\hline & & & Booth registrasi & Area registrasi \\
\hline
\end{tabular}




\begin{tabular}{|c|c|c|c|c|}
\hline \multirow[t]{3}{*}{4} & $\begin{array}{l}\text { Peneliti/ } \\
\text { tamu }\end{array}$ & Datang, Masuk, Menyimpan barang bawaan & Loker & Selasar/teras \\
\hline & & registrasi & Booth Registrasi & Area registrasi \\
\hline & & $\begin{array}{l}\text {-Mengamati dan mencatat informasi material } \\
\text { dan pencahayaan } \\
\text {-Mendengarkan dan mengamati penjelasan } \\
\text { laboran/ KaLab } \\
\text {-melakukan riset }\end{array}$ & $\begin{array}{l}\text { Meja kerja } \\
\text { Kursi, display lighting, }\end{array}$ & $\begin{array}{l}\text { Area display } \\
\text { Area Diskusi } \\
\text { Area Lighting display }\end{array}$ \\
\hline
\end{tabular}

Berdasarkan hasil penelitian tersebut maka ditemukan kebutuhan ruang dan besarannya adalah sebagai berikut:
1. Area selasar untuk loker : : $2 \mathrm{~m} 2$
2. Area registrasi : $2 \mathrm{~m} 2$
3. Area Kepala lab/laboran $\quad: 3 \mathrm{~m} 2$
4. Area display material $\quad: 12 \mathrm{~m} 2$
5. Area display pencahayaan $: 12 \mathrm{~m} 2$
6. Area diskusi/ kuliah/ eksperimen : $33 \mathrm{~m} 2$
7. Toilet : diluar ruangan

Selain menghasilkan daftar kebutuhan dan besaran area/ruang, penelitian juga menghasilkan alur pola kegiatan yang terjadi di ruang laboratorium dan sistem pencahayaan. Alur kegiatan ini didapatkan dengan mengamati pola pergerakan aktivitas yang terekam dalam kegiatan simulasi penggunaan lab. Pola tersebut berulang dengan konsisten dan kemudian dicatat serta dilakukan analisa untuk mendapatkan rekaan alur aktivitas umum yang terjadi.

Berdasarkan pola aktivitas yang terjadi dan besaran ruang yang dibutuhkan maka tahap selanjutnya adalah menentukan kelompok ruang (area) atau sonasi.

Gambar desain konsepsual dimulai pada gambar layout tata letak ruang. Oleh karena tidak ada perubahan fisik ruang, maka layout tata letak ruang tetap menggunakan layout eksisting. Perubahan terjadi pada gambar denah selanjutnya yakni denah penataan fasilitas. Merujuk pada gambar sonasi yang telah disampaikan, penataan fasilitas mengikuti zona atau area sesuai dengan kegiatan yang terjadi di dalamnya. Beikut ini merupakan gagasan denah penataan fasilitas terpilih yang telah melalui proses analisis.

Untuk mendapatkan visual yang lebih baik dan informatif serta melengkapi dokumen konsepsual, maka langkah selanjutnya adalah pembuatan gambar perspektif, dengan sketsa-sketsa manual dan kemudian di ubah ke dalam gambar 3D (3 Dimensi) format digital menggunakan software SketchUp dan 3D Max rendering. Sketsa-sketsa perspektif diawali dengan sketsa suasana ruang dan sketsa fasilitas ruang. Fasilitas ruang dirancang dengan konsep pragmatis sesuai dengan kebutuhan pengguna ruang dan menyisipkan teknologi di dalamnya, baik teknologi digital maupun konvensional. Pemilihan material yang kuat, tahan api dan air, serta mudah dalam perawatannya menjadi kriteria utama dalam menentukan bentuk desain dan material penyusunnya. Berikut ini merupakan visual 3 dimensi konsepsual yang sudah menggunakan software SketchUp dan 3D rendering untuk menampilkan keseluruhan bentuk ruang laboratorium beserta fasilitas yang terdapat di dalamnya.

View dari meja laboran menampilkan sudut tenggara ruangan. Melalui Gambar 6 dapat dilihat kondisi rancangan ruangan laboratorium dengan fasilitas berupa meja, kursi dan rak display material serta display sistem pencahayaan di dinding dan plafond. Pada lantai juga menggunakan kombinasi beberapa material dengan tujuan agar mahasiswa dapat belajar mengenai material penyusun lantai dan teknik detail pemasangannya.

Gambar 7 menunjukkan sudut pandang ke arah selatan ruangan dari arah utara. Nampak pada bagian tengah ruangan adalah area yang digunakan sebagai area diskusi, eksperimen maupun menerima materi perkuliahan dengan kapasitas maksimal 1820 orang dalam satu waktu bersamaan. Pada dinding kiri (bagian Timur ruangan) juga dipenuhi dengan rak display untuk menempatkan material board serta menyimpan katalog material. Melalui gambar ini juga terlihat jelas penggunaan lantai laminate flooring dipadukan dengan granit dan keramik motif marmer dalam upaya memberikan contoh secara langsung mengenai bahan pembentuk lantai ruangan pada mahasiswa.

Pada Gambar 8 terlihat sudut pengambilan gambar rancangan dari arah timur kearah barat ruangan. Tampak jelas plafond tambahan dirancang sebagai 


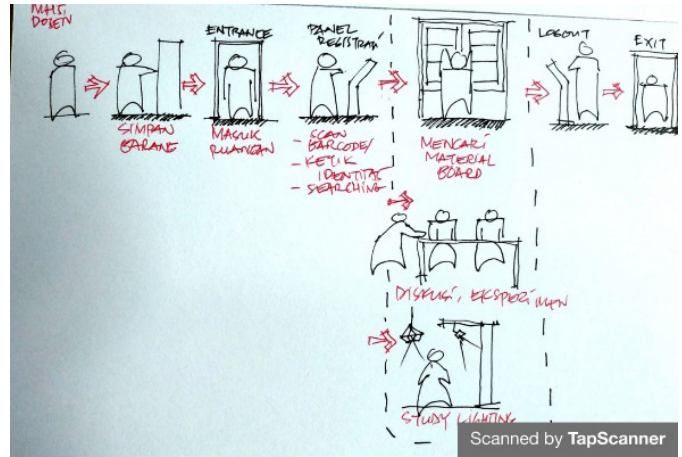

Gambar 3. Sketsa alur kegiatan umum dalam laboratorium

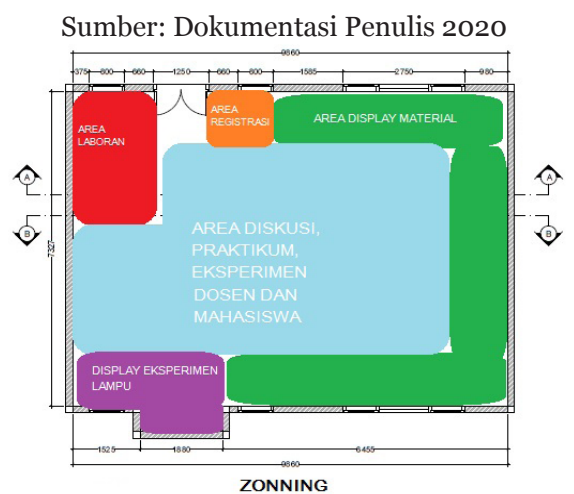

Gambar 4. Gambar Sonasi (zoning)

Sumber: Dokumentasi Penulis 2020

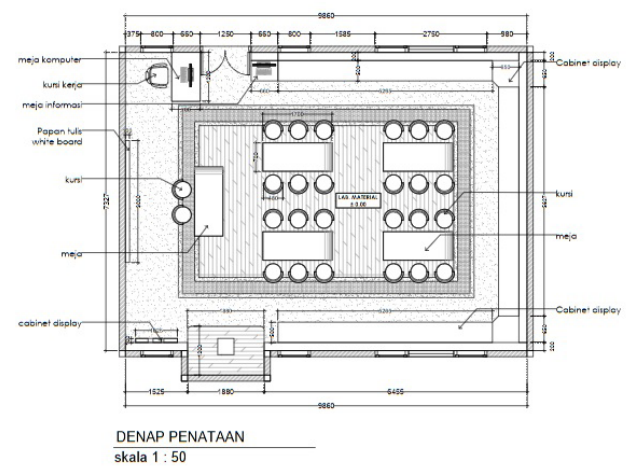

Gambar 5. Denah Penataan Laboartorium Material dan Sistem Pencahayaan

Sumber: Dokumentasi Penulis 2020

penempatan berbagai jenis sistem pecahayaan terutama yang terletak pada bagian atas ruang. Lampu dengan sistem spotlight track, concealed led strip maupun general lighting berupa neon bak serta downlight dengan armature tanam disematkan pada media peraga untuk mendapatkan efek cahaya yang langsung dilihat dan dirasakan dalam ruang oleh pengguna laboratorium. Pada dinding barat terpasang sebuah white board dan layar projector gulung yang dapat digunakan sebagai fasilitas penyampaian materi perkuliahan.

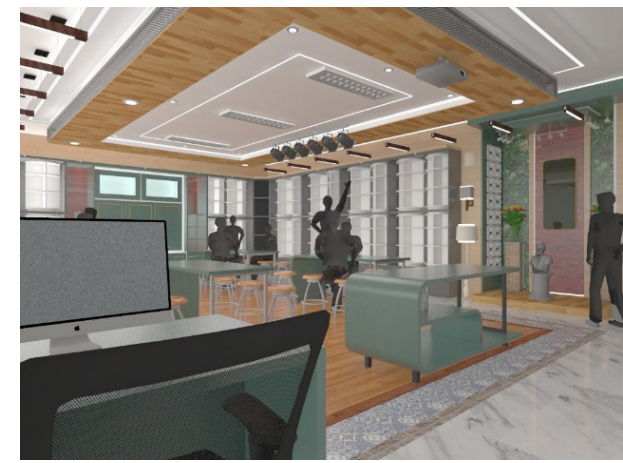

Gambar 6. Perspektif view dari meja laboran Sumber: Dokumentasi Penulis 2020

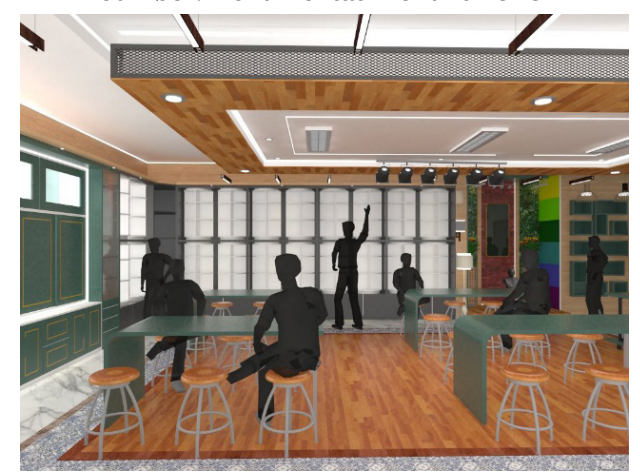

Gambar 7. Gambar Perspektif ke arah selatan ruang laboratorium Sumber: Dokumentasi Penulis 2020

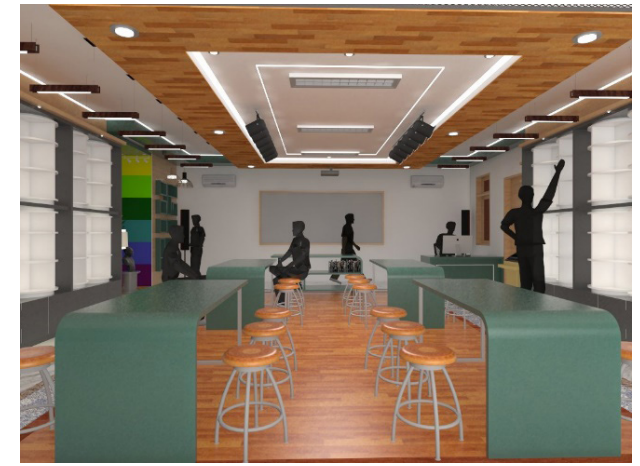

Gambar 8. Gambar Perspektif ke arah barat ruang laboratorium Sumber: Dokumentasi Penulis 2020

Rancangan konsepsual laboratorium ini berupaya untuk menampilkan sebanyak mungkin jenis material dan sistem pencahayaan yang sering digunakan dalam perancangan interior. Opsi-opsi kombinasi material maupun sistem pencahayaan diharapkan dapat dilakukan di laboratorium ini untuk memperkaya pilihan dalam mendesain dan bahkan menghasilkan trend baru dalam merancang interior. 


\section{SIMPULAN}

Berdasarkan pejabaran diatas maka dapat ditarik kesimpulan bahwa perancangan Laboratorium Material dan Sistem Pencahayaan di PS/Jurusan Desain Interior ISI Denpasar dilakukan dengan tahapan penelitian mengenai aktivitas pengguna ruang (civitas) dengan metode partisipatoris. Hasil penelitian tersebut menghasilkan pola atau skenario aktivitas yang menjadi titik tolak perancangan. Konsep Smart Integrated Lab kemudian menjadi benang merah untuk solusi kebutuhan rancangan laboratorium. Rancangan ini berdasar pada kebutuhan idealita civitas, konsep, review literature serta kriteria perancangan. Rak display moodboard material, aplikasi hardware, serta penempatan armature lampu sekaligus ditampilkan pada furniture dan ruangan sehingga mahasiswa dapat belajar mengenai aplikasi material dan sistem pencahayaan secara langsung. Dengan demikian pencapaian hasil maksimal dari segi mutu dan kualitas pembelajaran diharapkan dapat tercapai. Selain itu, pengembangan keilmuan melalui penelitian-penelitian yang dilakukan di laboratorium material dan sistem pencahayaan juga diharapkan akan semakin meningkat dan memberikan kontribusi nyata bagi PS/Desain Interior ISI Denpasar, mahasiswa dan masyarakat pada umumnya.

\section{DAFTAR RUJUKAN}

Decapri, R. ed. Yulianto, D. 2013. Tips Mengelola Laboratorium Sekolah. Yogyakarta: Diva Press

Darmasetiawan, C., Puspakesuma, L. 1991. Teknik Pencahayaan dan Tata Letak Lampu. Jakarta: Grasindo

Dodsworth, S. 2009. The Fundamental of Interior Design. Lausanne: AVA Publishing

Kilmer, R \& Kilmer, W.O. 1992. Designing Interiors. Wadswoth Publishing

Leinonen, T \& Durall, E. 2014. Design Thinking and Collaborative Learning. Jurnal COMUNICAR, vol 21, No 42. P 107-115

Setiawan, AP. 2005. Laboratorium Bahan Interior Sebagai Pendukung Keberhasilan Pembelajaran Desain Interior. Jurnal Dimensi Interior, Vol 3. No 1. Juni 2005, Hal : 65-79. 